\title{
Insect Fauna Associated with Exposed Pig Carcasses in Southern Brazil
}

\author{
Ana Carolina Ries ${ }^{\bowtie}$ \& Betina Blochtein
}

Pontifícia Universidade Católica do Rio Grande do Sul, e-mail: anacarolinaries@hotmail.com (Autor para correspondência ${ }^{\bowtie}$ ), betinabl@pucrs.br.

\section{EntomoBrasilis 8 (3): $180-188$ (2015)}

\begin{abstract}
The knowledge of insect patterns visiting decomposing carcasses and the analysis of parameters related to their presence help determine the post-mortem interval (PMI). This information depends on regional studies because the diversity of insects and the environmental conditions interfere in this process. The aim of the study was to analyze the insect fauna that colonizes carcasses of pigs exposed in different stages of decomposition in the study area. The experiment was conducted in southern Brazil using three domestic pigs (Sus scrofa Linnaeus) that were killed on site. Adult insects associated with carcasses were sampled daily using an insect net, manual collection and pitfall traps. Statistical tests were performed to evaluate the diversity of insects. During the process of decomposition (14 days), Scarabaeidae (25\%) and Calliphoridae (23\%) species were the most abundant of all of the samples. The diversity of insects is distinguishable when all parameters are analyzed. The Black Putrefaction (IV) stage exhibited the highest diversity according to the applied methods. The succession pattern was established from the species dominance index: Fresh stage - Lucilia eximia Wiedemann (Diptera, Calliphoridae); Chromatic and Bloat - Chrysomya albiceps (Wiedemann) (Diptera, Calliphoridae); Black Putrefaction and Skeletonization - Aphodiinae sp. 1 (Coleoptera, Scarabaeidae).
\end{abstract}

Keywords: Colonization; forensic entomology; postmortem interval; scavenger insects; Sus scrofa.

\section{Entomofauna Associada a Carcaças de Suínos Expostas no Sul do Brasil}

Resumo. O conhecimento dos padrões de insetos que visitam carcaças em decomposição e a análise dos parâmetros relacionados a sua presença auxilia na determinação do intervalo post-mortem (IPM). Estas informações dependem de estudos regionais, pois a diversidade de insetos e as condições ambientais interferem neste contexto. O objetivo do estudo foi analisar a entomofauna que coloniza carcaças expostas em diferentes estágios de decomposição na área de estudo. O experimento foi conduzido no sul do Brasil utilizando três porcos domésticos (Sus scrofa Linnaeus), abatidos no local. Insetos adultos associados às carcaças foram amostrados diariamente com rede entomológica, coleta manual e armadilhas pitfall. Foram realizados testes estatísticos para avaliar a diversidade de insetos. Durante o processo de decomposição (14 dias), espécimes de Scarabaeidae (25\%) e Calliphoridae (23\%) foram os mais abundantes, considerando-se a totalidade das amostras. A diversidade de insetos é distinguível quando são analisados todos os parâmetros. A fase de Putrefação negra (IV) exibiu a maior diversidade de acordo com os métodos aplicados. O padrão de sucessão foi estabelecido a partir do índice de dominância das espécies: fase Fresca - Lucilia eximia Wiedemann (Diptera, Calliphoridae), fase Cromática e de Inchamento - Chrysomya albiceps (Wiedemann) (Diptera, Calliphoridae), e fase de Putrefação Negra e de Esqueletização - Aphodiinae sp. 1 (Coleoptera, Scarabaeidae).

Palavras-chave: Colonização; entomologia forense; intervalo post-mortem; insetos necrófagos; Sus scrofa.

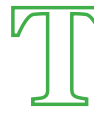
The use of insects in criminal investigations relies on the fact that they are present at all stages of decomposition and in a predictable sequence (PAYNE 1965; Dillon 1997). In addition, certain insect species are characteristic of certain geographic regions (PAYNe 1965; ANDERSON \& VANLAERHOVEN 1996). Many species participate in the insect colonization of the carcass, triggering a process of succession; if the succession pattern is constant and know, it can be highly informative (Mise et al. 2007). Thus, the study of insects associated with dead bodies may assist in solving crimes and their surrounding circumstances (Ммітн 1986; Catts \& Haskel 1990; Anderson \& Hobischak 2004).

The decomposition of a corpse is characterized by a continuous process that starts at the time of death and ends when the carcass is reduced to a skeleton. Although continuous, the process is divided into stages to facilitate research studies (GoFF 1993; BorNEMISSZA 1956). Each stage of decomposition provides a favorable microenvironment for certain insect species, causing certain groups to colonize the carcass; this establishes a predictable chronological sequence (PAYNE 1965; BorNEMISSZA 1956; VASCONCELOS \& ARAUJO 2012).

The recognition of entomological species that colonize carcasses and their development at different temperatures provide an estimated time of death (SMith 1986; GreEnberg 1991). CAtTs \& HASKELL (1990) emphasized the influence of several factors that should be considered when estimating the post-mortem interval; these factors may change the arrival and colonization of insects. The weather, particularly the temperature and humidity, exerts great influence on the decomposition and insect succession pattern (SHEAN et al. 1993; ARCHER 2004). Besides, scavenger insects have different synanthropy indices, determined by their abundance in a particular ecological area; this classification system was established by GREGOR \& POLVONY (1958). For example, representatives of Calliphoridae, in general, are typical of urban environments (FERREIRA 1978), which have a higher incidence of homicide (ANDERSON 2011).

Studies on the succession of insects colonizing decaying carcasses have been conducted in tropical and subtropical areas (MARTINEZ et al. 2007), and show that the composition and diversity of species varies in relation to geographic region and abiotic factors (GoFf 1993).

In the last two decades, the homicide rate in Brazil grew by $41 \%$, with an average of 27.1 deaths per 100,000 inhabitants

Funding Agency: CAPES 
T (IBGE 2013). Many cases remain unsolved due to difficulties in the criminal investigation procedures. Complementing the advances in biological research, tools that utilize ecological and entomological data are being routinely implemented by forensic scientists in Brazil (VASCONCELOS \& ARAUJO 2012).

Considering the need for regional information to support criminal expertise, as many factors influence the process of animal tissue decomposition, we examined the successional pattern of adult insects associated with carcasses at various stages of decomposition in southern Brazil.

\section{MATERIAL AND METHODS}

The study investigating the fauna that colonize carcasses of domestic pigs was conducted in December 2011 in Viamão, the metropolitan area of Porto Alegre in Rio Grande do Sul, southern Brazil. This location has an altitude of 52 meters and coordinates of $30^{\circ} 02^{\prime} 10,47^{\prime \prime} \mathrm{S}, 51^{\circ}$ 01'19, $05^{\prime \prime} \mathrm{O}$. Carcasses of domestic pigs (Sus scrofa Linnaeus) were placed in pasture area at the Station Research and Production Fine Waters of the State Foundation for Agricultural Research, which belongs to the Secretariat of Agriculture, Livestock and Agribusiness of the State of Rio Grande do Sul; the area had a size of 150 ha. The study encompasses the ecoclimatic region of the Central Depression (MALUF \& CAIAFFo 2001), where the climate is classified as Cfa type according to Koppen (subtropical, humid climate with hot summers). The average maximum temperature is $28^{\circ} \mathrm{C}$, and the average minimum is $20^{\circ} \mathrm{C}$ in the summer (KUINCHTNER \& BURIOL 2001). The average annual rainfall is $1,322 \mathrm{~mm}$, and the rainfall is well distributed throughout the year (Moreno 1961). The soil is classified as typic Paleudalf soil (EMBRAPA 1999).

The characteristic vegetation in the Experimental Station includes fields with native Ficus organencis (Micah) Mic, and vegetation in recovery are marked by grasses and bromeliads Eryngium horridum Malme. In the subtropical forest region, Syagrus romanzoffiana (Cham.) Glassman is abundant, and Erythryna cristagalli $\mathrm{L}$ can be found in the wetland regions. The land in the Station is used for agricultural and livestock activities and its surrounding areas are dominated by urban centers.
We used three domestic pigs (S. scrofa) for our animal model. All of the pigs were male and weighed approximately $16 \mathrm{~kg}$. The age and color of all three pigs were similar. They were slaughtered with a .38 caliber firearm using a shot to the occipital region, and they died immediately. Anesthesia and sedatives were not used because these drugs influence the rate of carcass decomposition (INTRONa et al. 2001) and the development of insect colonies on the substrate, changing the estimated post-mortem interval (PMI) (GOFF \& LORD 1994).

Treatment of the animals followed the recommendations set forth by the National Council for Control of Animal Experimentation (CONCEA) and legislation (Arouca Law No. 11.794, of $08 / 10 / 2008$ ), in addition to Resolution 714 of the Federal Council of Veterinary Medicine. The Ethics Committee for Animal Use (CEUA) at the Pontifical Catholic University of Rio Grande do Sul approved the experiment (registration 152 dated of 28/11/2011).

Immediately after death, the carcasses were placed in right lateral decubitus in metal mesh boxes $\left(1.5 \mathrm{~cm}^{2}\right)$ with dimensions of 100 $\mathrm{cm} \times 70 \mathrm{~cm} \times 60 \mathrm{~cm}$. Mesh boxes were used to repel vertebrate carnivores and to allow insect fauna to access the carcasses. These boxes were placed in an area with herbaceous vegetation, approximately $1 \mathrm{~m}$ from the edge of a remnant native forest. The boxes were spaced out, such that $10 \mathrm{~m}$ separated them, and all boxes were placed under similar exposure conditions. Six pitfall traps (plastic cups $300 \mathrm{~mL}$ ) were placed around each box to collect insects (Figure 1). These traps contained water and a drop of detergent to break the surface tension of the water (KEARNS \& INouYe 1993), and the contents were replaced daily after collection. These traps were placed $10 \mathrm{~cm}$ from the box and were equidistant from each other.

The experiment was conducted between December 7-20, 2011, and the several activities were performed daily: a) observation of carcasses and characterization of decomposition stages from putrefaction phenomena (Gomes 1997), b) record of carcasses and insect fauna present using a FujiFilm Finepix S4500 camera and c) collection of insects. Three sampling methods were used, and the cages were removed to allow sampling. Hand nets were placed on each carcass for 10 minutes, and used in order to

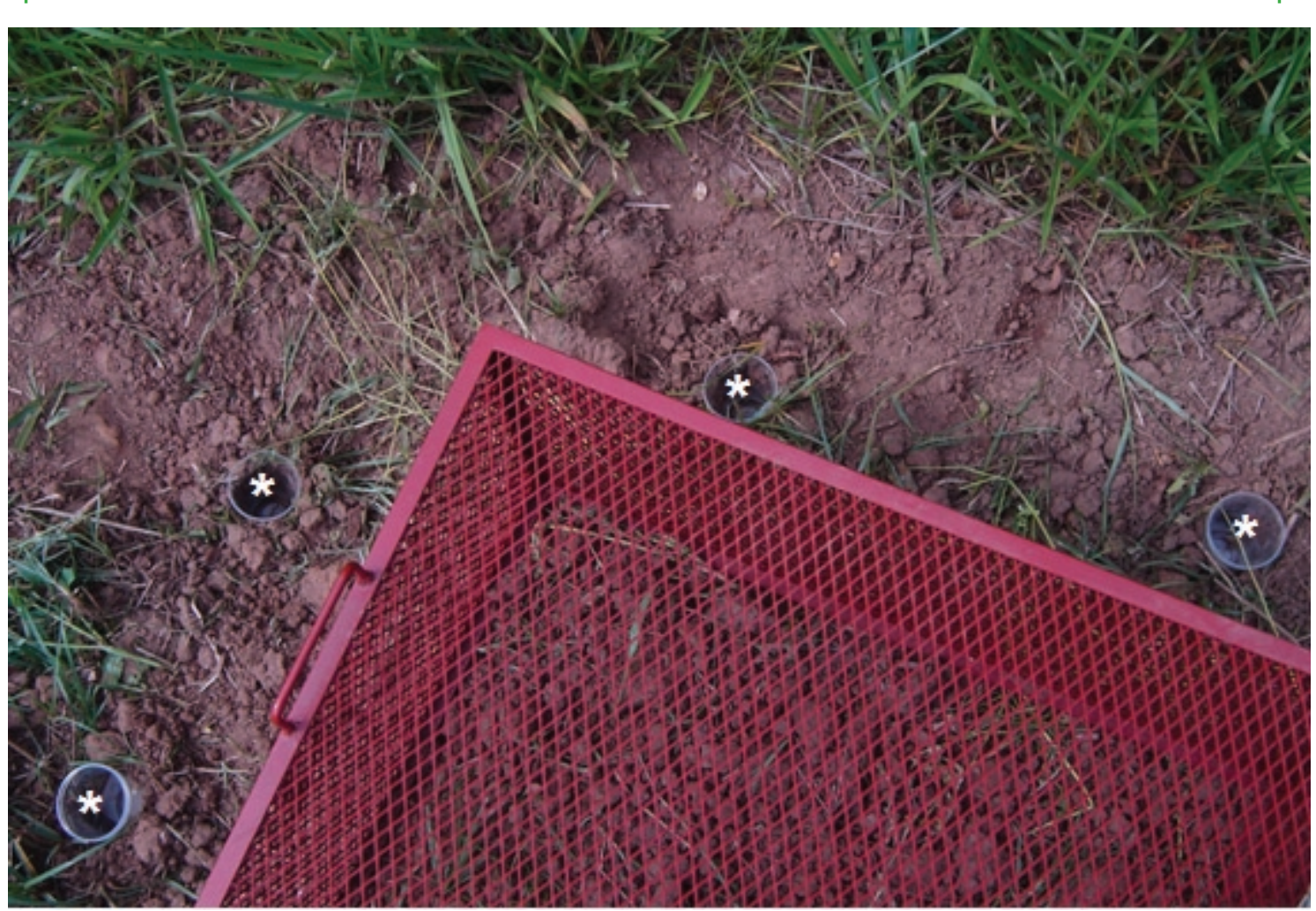

Figure 1. Picture of the $1.5 \mathrm{~cm}^{2}$ wire mesh box and the arrangement of the pitfall traps $\left(^{*}\right)$ around the box. 
capture adult insects that were in flight near the carcasses. The collected insects were transferred to killing chambers containing ethyl acetate. For manual collection, carcasses were inspected for 10 minutes, and adult insects present on and around the carcasses were collected using tweezers. Finally, insects in the pitfall traps were harvested. Samples were collected at the same time (12:00 to 13:00 h) each day and by the same operator, minimizing variations in sampling. Insects collected manually and from the pitfall traps were preserved in 70\% alcohol. The insects were incorporated into the Insect Collection of the Museum of Science and Technology (MCT), Pontifical Catholic University of Rio Grande do Sul. The specimens were identified using taxonomic keys, the reference collection of insects, and when necessary, with the help of experts.

Daily records for the experimental period (07/12/2011 to 20/12/2011), including temperature, relative humidity and rainfall, were obtained from the 8th District of Meteorology of Porto Alegre / National Institute of Meteorology (INMET 2012).

Given the proximity of the metal cages, we applied the KruskalWallis test using Palaeontological Statistics (PAST), version 2.17b (Hammer et al. 2001), to compare the diversity of insects in the three pig carcasses during the decomposition process to determine whether the data from the treatments could be pooled.

The diversity of the insect fauna colonizing the decomposing pig carcasses during the experiment was evaluated using the Margalef, Shannon, Simpson and Pielou Equitability diversity index. All diversity index calculations were performed from the number of records for each family of insects and for each decomposition stage of the carcasses; these indices were calculated using PAST software, version 2.17b (HAMmeR et al. 2001).

The constancy term represents the proportion of days in which the insect species in question was sampled and the total number of days sampled was based on the study by Silveira Neto et al. (1976). Also based on the Silveira Neto et al. study (1976), the following categories were used: constant $=>50 \%$, accessory
$=>25-50 \%$ and accidental $=<25 \%$. The dominant species was estimated according to the parameters established by FRIEBE (1983); these parameters are: eudominant $>10 \%$ dominant $>$ $5-10 \%$, subdominant $>2-5 \%$, recessive $>1-2 \%$ and rare $<1 \%$. To express the abundance of various sampled insect species, the following calculation was used: $\mathrm{D} \%=(\mathrm{i} / \mathrm{t}) \times 100$, where $i$ is the total number of individual species, and $t$ is the total number of collected individuals.

A Pearson correlation for parametric data was performed using the Statistical Package for the Social Sciences (SPSS 2006). This analysis utilized the raw insect abundance data for each collection day and daily average temperature and relative humidity.

To assess whether the sampling was adequate, we used a curve rarefaction (KREBS 1999), comparing the insect species richness with the number of insects sampled. Indices were calculated using Sobs, Chao 1 and 2, Jacknife first and second order and Bootstrap corrections. The richness estimators and rarefaction curves were obtained using the PRIMER statistical program, version 6.0 (CLARKE \& GORLEY 2006). A significance level of 5\% was used for all statistical analyses.

For classification of decomposition stages used in this study, please refer to the provision by Gomes (1997) for Neotropical countries.

\section{RESULTS}

Decomposition process of carcasses and environmental conditions. The decomposition of the carcasses lasted fourteen days, and five stages of decomposition were observed: Fresh (I), Chromatic (II), Bloat (III), Black Putrefaction (IV) and Skeletonization (V).

The duration of each decomposition stage was determined according to the physical changes observed in the exposed pig carcasses (Table 1).

The process of decay curve showed an asymmetric distribution in the number of insects associated with the carcasses; the

Table 1. Stages of decomposition and physical characteristics observed in pig carcasses exposed in Viamão, Brazil.

\begin{tabular}{llc}
\hline \multicolumn{1}{c}{ Stages of decomposition } & \multicolumn{1}{c}{ Physical characteristics } & Days post-mortem \\
\hline Fresh (I) & Fresh appearance, no odor & o \\
Chromatic (II) & Emergence of abdominal green stains and the beginning of gas accumulation & 1 \\
Bloat (III) & Swelling of the abdomen and the appearance of Circulation Posthumous Brouardel & 3 \\
Black Putrefaction (IV) & Complete deflation and intense carcass odor & 6 \\
Skeletonization (V) & Decreased odor; carcass consists primarily of bones, skin and hair. & 11 to 13 \\
\hline
\end{tabular}

peak was observed at day 5 , coinciding with the Bloated stage (Figure 2). During this period, the total precipitation was 31.7 $\mathrm{mm}$, characteristic of a dry and hot summer. The average daily temperature $\left(24.2^{\circ} \mathrm{C} \pm 1.59^{\circ} \mathrm{C}\right)$ and relative humidity $(67.1 \% \pm$ $6.49 \%$ ) were not correlated with the number of sampled insects ( $\mathrm{r}=0.221, \mathrm{p}=0.448$ and $\mathrm{r}=-0.345, \mathrm{p}=0.227$ for temperature and humidity, respectively) during the studied carcass decomposition period.

Faunal composition and ecological succession. The Kruskal-Wallis test indicated that there were no significant differences (p> 0.05) among the three $S$. scrofa carcasses used in the study with respect to the diversity of insects at each decomposition stage. Due to this finding, the data were grouped to determine the pattern insect fauna succession for the three carcasses.

The sampling next to the pig carcasses produced 569 adult insects belonging to 29 families, 55 genera and 68 morphospecies. Representatives of Scarabaeidae (25\%), Calliphoridae (23\%), Muscidae (14.2\%), Formicidae (9.6\%) and Sarcophagidae (8\%) were the most abundant (Table 2). The presence of insects next to the carcasses was observed from one hour after death until the end of the decomposition process.

Among the species collected, the Eudominants ( $>10 \%$ prevalence) were Chrysomya albiceps (Wiedemann), Ophyra aenescens (Wiedemann) and Aphodiinae sp. 1. The only dominant species ( $>5 \%$ prevalence) observed was Sarcophagidae sp. 1 . There were six subdominant ( $>2 \%$ prevalence species collected: Musca domestica Linnaeus; Piophilidae sp. 1; Euspilotus nigrita Blanchard; Camponotus rufipes Fabricius; Iridomyrmex sp. 1; and Rhopalidae sp. 1. All of the other species were classified as rare or recessive, and eight morphospecies were classified as constant, present in more than $50 \%$ of sampling days: C. albiceps, O. aenescens, Ophyra albuquerquei Lopes, Sarcophagidae sp. 1, E. nigrita, Aphodiinae sp. 1, Scarabaeinae sp. 1 e Iridomyrmex sp. 1 (Table 2).

The Black Putrefaction stage (IV) had the greatest diversity of insect species, with the presence of 24 insect families and 271 individual insects. The Fresh stage (I) was the least rich, with only 4 families and 13 individuals collected (Table 2). 


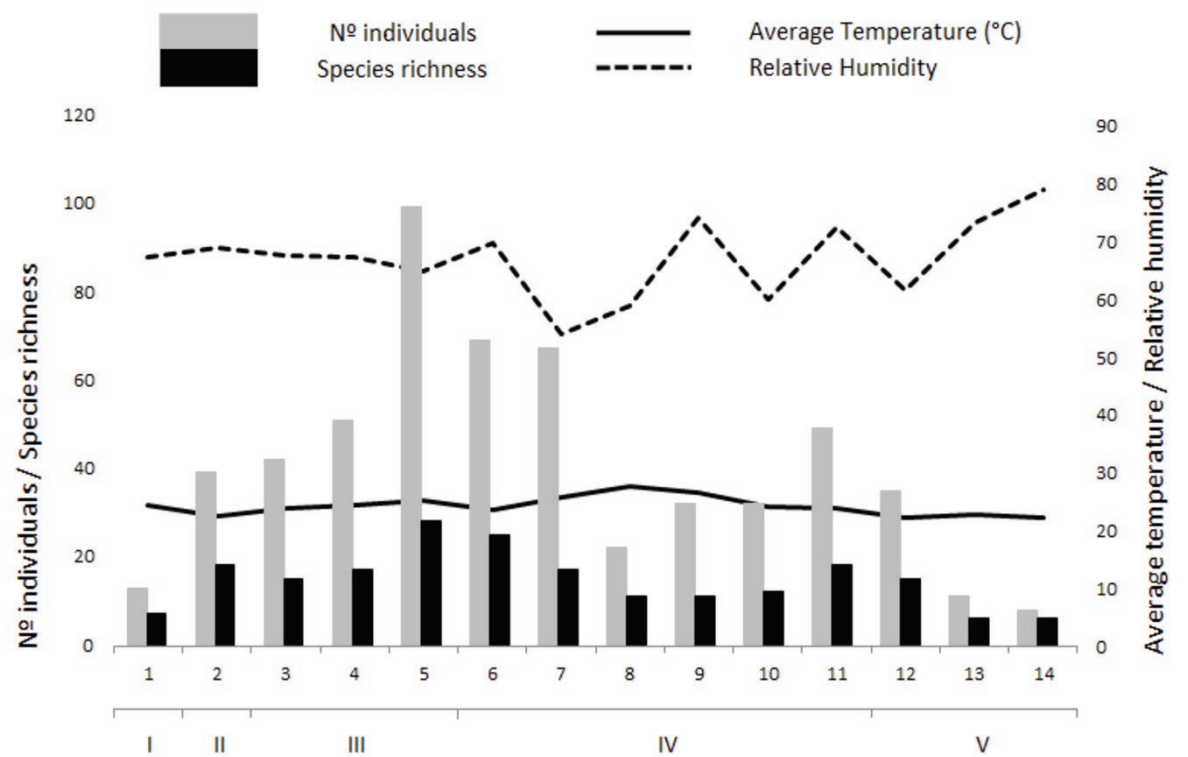

Figure 2. The number of individuals and insect species richness observed in pig carcasses during the 5 stages of decomposition (I - Fresh, II Chromatic, III - Bloat, IV - Black Putrefaction and V - Skeletonization) relative to the daily average temperature and relative humidity values during the study period (o7 to 20 December 2011 in Viamão, Brazil).

Table 2. Insects collected from pig carcasses exposed in Viamão, Brazil. The number of individuals (NI) were recorded for each carcass decomposition stage (SD: I, Fresh; II, Chromatic; III, Bloat; IV, Black Putrefaction; and V, Skeletonization). The frequency (F), Dominance (D), Constance (C) and status (A, accessory; Ac, accidental; C, constant; ED, eudominant; SD, subdominant; D, dominant; Rc, recessive; and R, rare) are also provided.

\begin{tabular}{|c|c|c|c|c|c|}
\hline Taxon & NI & SD & F (\%) & $\mathbf{D}$ & $\mathbf{C}$ \\
\hline \multicolumn{6}{|l|}{ DIPTERA } \\
\hline CALLIPHORIDAE & & & 23.02 & & \\
\hline Calliphora vicina Robineau-Desvoidy & 1 & I & 0.18 & $\mathrm{R}$ & Ac \\
\hline Chrysomya albiceps (Wiedemann) & 109 & I, II, III, IV, V & 19.16 & $\mathrm{ED}$ & $\mathrm{C}$ \\
\hline Chrysomya megacephala (Fabricius) & 1 & IV & 0.18 & $\mathrm{R}$ & Ac \\
\hline Chrysomya putoria (Wiedemann) & 3 & III & 0.53 & $\mathrm{R}$ & Ac \\
\hline Cochliomyia macellaria (Fabricius) & 6 & I, II, III & 1.05 & $\mathrm{Rc}$ & A \\
\hline Hemilucilia semidiaphana (Rondani) & 3 & I, III, IV & 0.53 & $\mathrm{R}$ & Ac \\
\hline Lucilia eximia (Wiedemann) & 8 & I, III, IV & 1.41 & $\mathrm{Rc}$ & Ac \\
\hline FANNIDAE & & & 1.93 & & \\
\hline Fannia sp. 1 & 9 & III, IV & 1.58 & $\mathrm{Rc}$ & Ac \\
\hline Fannia pusio (Wiedemann) & 1 & IV & 0.18 & $\mathrm{R}$ & Ac \\
\hline Fannia trimaculata (Stein) & 1 & IV & 0.18 & $\mathrm{R}$ & Ac \\
\hline LAUXAMIIDAE & & & 0.18 & & \\
\hline Lauxamiidae sp. 1 & 1 & IV & 0.18 & $\mathrm{R}$ & Ac \\
\hline MUSCIDAE & & & 14.24 & & \\
\hline Biopyrellia bipuncta (Wiedemann) & 2 & III, IV & 0.35 & $\mathrm{R}$ & Ac \\
\hline Musca domestica Linnaeus & 12 & II, III, IV & 2.11 & SD & A \\
\hline Ophyra aenescens (Wiedemann) & 57 & II, III, IV, V & 10.02 & $\mathrm{ED}$ & $\mathrm{C}$ \\
\hline Ophyra albuquerquei Lopes & 9 & II, III, IV & 1.58 & $\mathrm{Rc}$ & $\mathrm{C}$ \\
\hline Ophyra solitaria Albuquerque & 1 & II & 0.18 & $\mathrm{R}$ & Ac \\
\hline PIOPHILIDAE & & & 3.16 & & \\
\hline Piophilidae sp. 1 & 13 & III, IV & 2.28 & $\mathrm{SD}$ & A \\
\hline Piophilidae sp. 2 & 4 & III, IV & 0.70 & $\mathrm{R}$ & Ac \\
\hline Piophilidae sp. 3 & 1 & III & 0.18 & $\mathrm{R}$ & Ac \\
\hline SARCOPHAGIDAE & & & 8.08 & & \\
\hline Blaesoxipha denieri (Blanchard) & 3 & IV & 0.53 & $\mathrm{R}$ & Ac \\
\hline Blaesoxipha lanei (Lopes) & 1 & $\mathrm{~V}$ & 0.18 & $\mathrm{R}$ & Ac \\
\hline Microcerella halli (Engel) & 2 & IV, V & 0.35 & $\mathrm{R}$ & Ac \\
\hline
\end{tabular}

to be continued... 
Table 2. continued...

\begin{tabular}{|c|c|c|c|c|c|}
\hline Taxon & NI & SD & F (\%) & $\mathbf{D}$ & $\mathbf{C}$ \\
\hline Oxysarcodesia thornax (Walker) & 6 & III, IV & 1.05 & $\mathrm{Rc}$ & Ac \\
\hline Oxysarcodesia avuncula (Lopes) & 1 & $\mathrm{~V}$ & 0.18 & $\mathrm{R}$ & Ac \\
\hline Ravinia belforti (Prado \& Fonseca) & 4 & III, IV, V & 0.70 & $\mathrm{R}$ & A \\
\hline Sarcophagidae sp. 1 & 29 & II, III, IV, V & 5.10 & $\mathrm{D}$ & $\mathrm{C}$ \\
\hline SIRPHIDAE & & & 0.18 & & \\
\hline Toxomerus sp. 1 & 1 & $\mathrm{~V}$ & 0.18 & $\mathrm{R}$ & Ac \\
\hline STRATIOMYIDAE & & & 0.53 & & \\
\hline Hermetia illucens (Linnaeus) & 3 & III, IV, V & 0.53 & $\mathrm{R}$ & Ac \\
\hline TABANIDAE & & & 0.53 & & \\
\hline Tabanus sp. 1 & 3 & $\mathrm{I}, \mathrm{IV}, \mathrm{V}$ & 0.53 & $\mathrm{R}$ & Ac \\
\hline \multicolumn{6}{|l|}{ COLEOPTERA } \\
\hline CARABIDAE & & & 0.18 & & \\
\hline Cicindelinae sp. 1 & 1 & IV & 0.18 & $\mathrm{R}$ & Ac \\
\hline CLERIDAE & & & 0.53 & & \\
\hline Necrobia ruficollis (Fabricius) & 1 & $\mathrm{~V}$ & 0.18 & $\mathrm{R}$ & Ac \\
\hline Necrobia rufipes (De Geer) & 2 & IV & 0.35 & $\mathrm{R}$ & Ac \\
\hline CURCULIONIDAE & & & 0.18 & & \\
\hline Naupactus auricinctus (Boheman) & 1 & $\mathrm{~V}$ & 0.18 & $\mathrm{R}$ & Ac \\
\hline DERMESTIDAE & & & 0.70 & & \\
\hline Dermestes maculatus (De Geer) & 4 & IV, V & 0.70 & $\mathrm{R}$ & Ac \\
\hline ELATERIDAE & & & 0.53 & & \\
\hline Conoderus abbreviatus (Germar) & 4 & II, III, IV & 0.70 & $\mathrm{R}$ & Ac \\
\hline Elateridae sp. 1 & 3 & II, III & 0.53 & $\mathrm{R}$ & Ac \\
\hline HISTERIDAE & & & 2.99 & & \\
\hline Euspilotus nigrita (Blanchard) & 17 & III, IV & 2.99 & $\mathrm{SD}$ & $\mathrm{C}$ \\
\hline HYDROPHILIDAE & & & 0.18 & & \\
\hline Hydrophilidae sp. 1 & 1 & IV & 0.18 & $\mathrm{R}$ & Ac \\
\hline SCARABAEIDAE & & & 25.13 & & \\
\hline Aphodiinae sp. 1 & 126 & II, III, IV, V & 22.14 & ED & $\mathrm{C}$ \\
\hline Canthon sp. 1 & 1 & III & 0.18 & $\mathrm{R}$ & Ac \\
\hline Canthon mutabilis (Lucas) & 1 & IV & 0.18 & $\mathrm{R}$ & Ac \\
\hline Eurysternus parallelus (Castelnau) & 1 & II & 0.18 & $\mathrm{R}$ & Ac \\
\hline Onthophagus sp. 1 & 1 & IV & 0.18 & $\mathrm{R}$ & Ac \\
\hline Scarabaeinae sp. 1 & 7 & III, IV, V & 1.23 & $\mathrm{Rc}$ & $\mathrm{C}$ \\
\hline Uroxys sp. 1 & 2 & III & 0.35 & $\mathrm{R}$ & Ac \\
\hline SCIRTIDAE & & & 0.18 & & \\
\hline Scirtidae sp. 1 & 1 & IV & 0.18 & $\mathrm{R}$ & Ac \\
\hline SILPHIDAE & & & 1.76 & & \\
\hline Oxelytrum discicolle (Brullé) & 10 & III, IV & 1.76 & $\mathrm{Rc}$ & A \\
\hline STAPHYLINIDAE & & & 0.18 & & \\
\hline Aleocharinae sp. 1 & 1 & IV & 0.18 & $\mathrm{R}$ & Ac \\
\hline \multicolumn{6}{|l|}{ HYMENOPTERA } \\
\hline APIDAE & & & 0.70 & & \\
\hline Scaptotrigona bipunctata (Lepeletier) & 4 & III, IV & 0.70 & $\mathrm{R}$ & Ac \\
\hline FORMICIDAE & & & 9.67 & & \\
\hline Acromyrmex sp. 1 & 4 & II, IV, V & 0.70 & $\mathrm{R}$ & A \\
\hline Atta sp. 1 & 2 & II, IV, V & 0.35 & $\mathrm{R}$ & Ac \\
\hline Camponotus sp. 1 & 8 & III, IV & 1.41 & $\mathrm{Rc}$ & A \\
\hline \multicolumn{6}{|l|}{ FORMICIDAE (Continued) } \\
\hline Camponotus rufipes Fabricius & 14 & II, III, IV & 2.46 & SD & A \\
\hline Ectatomma sp. 1 & 3 & II, III & 0.53 & $\mathrm{R}$ & Ac \\
\hline Formicidae sp. 1 & 8 & III, IV, V & 1.41 & $\mathrm{Rc}$ & $\begin{array}{c}\mathrm{Ac} \\
\text { to be continued... }\end{array}$ \\
\hline
\end{tabular}


Table 2. continued...

\begin{tabular}{|c|c|c|c|c|c|}
\hline Taxon & NI & SD & F (\%) & $\mathbf{D}$ & $\mathbf{C}$ \\
\hline Formicinae sp. 1 & 1 & III & 0.18 & $\mathrm{R}$ & Ac \\
\hline Iridomyrmex sp. 1 & 13 & III, IV, V & 2.28 & SD & $\mathrm{C}$ \\
\hline Odontomachus sp. 1 & 1 & $\mathrm{~V}$ & 0.18 & $\mathrm{R}$ & Ac \\
\hline Ponerinae sp. 1 & 1 & III & 0.18 & $\mathrm{R}$ & Ac \\
\hline VESPIDAE & & & 0.18 & & \\
\hline Polybia sericea (Olivier) & 1 & IV & 0.18 & $\mathrm{R}$ & Ac \\
\hline \multicolumn{6}{|l|}{ HEMIPTERA } \\
\hline LYGAEIDAE & & & 0.18 & & \\
\hline Lygaeidae sp. 1 & 1 & IV & 0.18 & $\mathrm{R}$ & Ac \\
\hline RHOPALIDAE & & & 2.99 & & \\
\hline Rhopalidae sp. 1 & 17 & I, II, III, IV, V & 2.99 & SD & Ac \\
\hline \multicolumn{6}{|l|}{ ORTHOPTERA } \\
\hline ACRIDIDAE & & & 0.53 & & \\
\hline Acrididae sp. 1 & 1 & III & 0.18 & $\mathrm{R}$ & Ac \\
\hline Dichroplus sp. 1 & 1 & III & 0.18 & $\mathrm{R}$ & Ac \\
\hline Ronderosia sp. 1 & 1 & IV & 0.18 & $\mathrm{R}$ & Ac \\
\hline GRYLLIDAE & & & 0.18 & & \\
\hline Gryllidae sp. 1 & 1 & II & 0.18 & $\mathrm{R}$ & Ac \\
\hline \multicolumn{6}{|l|}{ ODONATA } \\
\hline LIBELLULIDAE & & & 1.05 & & \\
\hline Libellulidae sp. 1 & 6 & I, II, III, IV, V & 1.05 & Rc & A \\
\hline \multicolumn{6}{|l|}{ LEPIDOPTERA } \\
\hline NYMPHALIDAE & & & 0.18 & & \\
\hline Diaethria clymena meridionalis (H. Bates) & 1 & III & 0.18 & $\mathrm{R}$ & Ac \\
\hline
\end{tabular}

The diversity of insects found in each carcass decomposition stage is distinguishable when all parameters are analyzed. The Black Putrefaction (IV) stage exhibited the greatest number of individuals and species, as well as the highest diversity according to the methods of Simpson (o.860), Shannon (2.779) and Margalef (8.211). In contrast, the lowest levels of diversity were observed in the Fresh stage (Margalef value $=2.339$ ). The Fresh stage also had the highest Pielou's Equitability index (0.838) due to reduced species diversity and high dominance (0.462). The Skeletonization (V) stage was characterized by a decrease in species abundance and species richness. This final stage was also defined by decreased diversity indices (Margalef $=5.014$ and Shannon $=2.380$ ), which resulted in an increased Pielou's Equitability index (0.782). These data suggest that the first and last decomposition stages are the most similar with respect to distribution diversity (Table 3).

The Berger-Parker dominance analysis was able to identify the dominance of particular morphospecies during each stage of carcass decomposition. The following key species were identified: Lucilia eximia Wiedemann - Fresh stage, C. albiceps - Chromatic and Bloat stages and Aphodiinae sp. 1 - Black Putrefaction and Skeletonization stages.

The projection of insect species richness in decomposing carcasses using multiple richness estimators (Sobs, Chao 1 and 2, Jackknife first and second order, and Bootstrap) does not reach an asymptote, according to rarefaction curve, suggesting that the number of samples was insufficient to observe rare species (Figure 3).

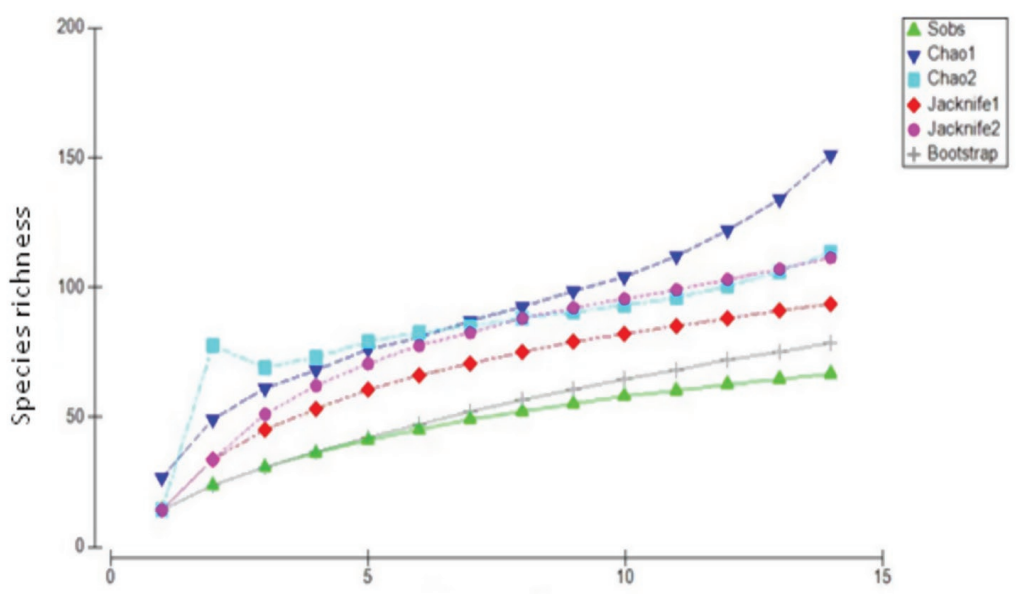

Number of samples

Figure 3. Estimates of insect species richness associated with pig carcasses in Viamão, Brazil. 
Table 3. Insect diversity, equitability and dominance indices during the pig carcass decomposition stages (I - Fresh stage, II - Chromatic, III - Bloat, IV - Black Putrefaction and V - Skeletonization) over the study period (07 to 20 December 2011 in Viamão, Brazil).

\begin{tabular}{|c|c|c|c|c|c|}
\hline Stages of Decomposition & $\mathbf{I}$ & II & III & IV & $\mathbf{V}$ \\
\hline Abundance & 13 & 39 & 192 & 271 & 54 \\
\hline Richness & 7 & 18 & 37 & 47 & 21 \\
\hline Margalef Diversity & 2.339 & 4.640 & 7.038 & 8.211 & 5.014 \\
\hline Shannon & 1.631 & 2.174 & 2.637 & 2.779 & 2.380 \\
\hline Simpson's Diversity & 0.734 & 0.767 & 0.843 & 0.860 & 0.821 \\
\hline Equitability of Pielou & 0.838 & 0.752 & 0.725 & 0.722 & 0.782 \\
\hline Berger-Parker dominance & 0.462 & 0.462 & 0.359 & 0.336 & 0.389 \\
\hline
\end{tabular}

\section{DISCUSSION}

In this study, five stages of decomposition were observed in pig carcasses, which supports the studies of Moura et al. (1997) and CARvalho et al. (2004). The decomposition progressed rapidly in most stages, as is expected during the summer in Neotropical countries (Moura et al. 1997; CARvalho \& Linhares 2001), and only bones and skin remained by day 14 .

The weather conditions during the study were recorded and characteristic of summer in the region. These conditions contributed to the accelerated decomposition process, which is in accordance with the findings of RodRiguez \& BASS (1983) and SHEAN et al. (1993). However, according to the Pearson correlation test, the meteorological factors were not associated with the number of individuals collected from the decomposing carcasses. This fact emphasizes that the maximum temperature is more important than the minimum temperature with respect to the rate of carcass decomposition; high relative humidity is also important because it acts directly on the decomposition of the carcasses and promotes the emergence of stage alternative decomposition by butyric fermentation, for example (MourA et al. 1997). However, the relationship between abiotic factors and the number of individuals collected is most evident when there is seasonal variation; this finding was proposed by the Carvalho \& Linhares (2001) study, which was conducted in São Paulo, southeastern Brazil. The CARvalHo \& Linhares (2001) study recorded low temperatures during the winter $\left(7.5^{\circ} \mathrm{C}\right)$ and found that lower temperatures were related to a low number of individuals; conversely, high temperatures in the summer $\left(29.2^{\circ} \mathrm{C}\right)$ were associated with a greater number of insects and more rapid decomposition. Because temperature and relative humidity conditions throughout the study exhibited little variation, it was not possible to demonstrate the influence of these factors on the presence of insects on the carcass or on the decomposition process itself.

The predominance of Scarabaeidae, Calliphoridae, Muscidae and Formicidae families observed during the study confirms the pattern observed by Moura et al. (1997), which was a similar study conducted in southern Brazil, but on smaller sized model corpses (rats). Members of these families, mainly Calliphoridae, are considered the main colonizers and consumers of this type of substrate (САмРовASSO et al. 2001). These families encompass the largest number of species due to their frequent use of animal matter, such as decaying site, for their development (STEvens 2003).

The predominance of individuals from the Calliphoridae family during the early stages of decomposition is attributed to the high perception of decay odors at great distances from the carcass (SMith 1986). Martinez et al. (2007) conducted a study in Paramo, Colombia, and they noted that the blowfly is observed during stages III and IV but not at the Skeletonization (V) stage. The rapid carcass weight loss is associated with the conversion of the carcass biomass to larval biomass; subsequently, larval insects leave the carcass during pupation. Rodriguez \& BASS (1983) indicated that flies from the Lucilia genus act as pioneers in the colonization of carcasses in Tennessee. Similarly, in the present study, L. eximia was the first species to reach the substrate and could be observed as soon as one hour after death.

The specie C. albiceps is originally from Africa and was introduced into Brazil in the 1970s (GuIMARÃEs et al. 1978). The current distribution of the blowfly encompasses nearly all of the national territory, as it is easily able to adapt and spread (ZuMPT 1965; Guimarães et al. 1983). The blowfly is also one of the first insects to colonize decomposing bodies, demonstrating its great potential for use during the search for forensic evidence (CARVALHO et al. 2004). However, their aggressive nature interferes with the colonization of other species, such as Cochliomyia macellaria (Fabricius) from the Calliphoridae family (FARIA et al. 2004; RosA et al. 2011). In addition, C. albiceps can be considered a keystone species in the determination of PMI, as this species shows no preference for station or geographical area (SOUZA \& LiNHARES 1997), and it has been found to be associated with several decaying resources, including human bodies (RodRIguEz \& BASS 1983; Oliveira \& VASCONCELOS 2010). In this study, C. albiceps was the most abundant species of blowfly in the samples and was present during all stages of decomposition. Rosa et al. (2011) also noted that this species was the most observed in decomposing carcasses in Cerrado. In another study also conducted in southern Brazil, VIANNA et al. (2004) reported a higher occurrence of the species during the warmer months, where temperatures ranged from $18.5^{\circ} \mathrm{C}$ to $23.5^{\circ} \mathrm{C}$. The findings from the Vianna et al. (2004) study are in accordance with what was observed in the present study. One factor that likely contributes to the high abundance of this species is the fact that it intensively consumes food over a short period of time (PRADO \& GUIMARÃES 1982) and their presence in subsequent stages may result from the production of new individuals from the carcass investigated. Among the families belonging to Coleoptera, Scarabaeidae was represented more than any of the others; Histeridae and Silphidae were the second and third most abundant families in this group. Such families are commonly associated with decaying carcasses, mainly as predators (Mise et al. 2007). Members of the Scarabaeidae family are also consumers of decaying matter (MARINONI et al. 2001). Aphodiinae sp. 1 was the most abundant within the Scarabaeinae subfamily, and this particular species was associated with the black putrefaction stage and is usually associated with manure. However, some species can feed on different types of carcass material from decaying plants and animals (Mise et al. 2007). The large number of individuals from this subfamily may be related to the sampling method used, the ability of this genus to dig into the carcass or the diversity of the species with respect habitat and food preferences (Scholtz \& GrebENNiKov 2005).

The Formicidae family was the taxon with the largest number of morphospecies in the decomposing carcasses (10 spp.), in agreement with other research studies (Monteiro-Filho \& Penereiro 1987; Cruz \& Vasconcelos 2006). Although few forensic studies have highlighted this taxonomic group, CRUZ \& VASCONCELOS (2006) emphasized the importance of ants associated with decomposing bodies in a region of the Atlantic Forest in Pernambuco; ants occupy different ecological niches and may accelerate decomposition. Camponotus spp. was the most abundant, supporting the results published by Moura et 
al. (1997) in Curitiba; this study recorded gender as important medico legal.

Regarding the stages of carcass decomposition, the largest number of insects was collected during Black Putrefaction, which can be attributed to a longer duration of this stage (six days). Additionally, this stage provides an increased availability of developmental resources for the insects, a fact that was also observed by Carvalho \& Linhares (2001) in São Paulo. The odor from the putrefied carcasses resulted in the greatest attraction of colonizers, both in terms of abundance and the diversity of insects. However, there was a low Equitability of Pielou index value, indicating an unequal distribution of this insect fauna on carcasses during this stage. This observation was related to high diversity and low dominance, and the Black Putrefaction stage became the most distinct stage in the entire decomposition process. The initial stages (I and II) were similar to the final stage of decomposition (V) with respect to the diversity index. The low diversity observed during the Fresh stage, as determined by the Margalef index, and the high distribution ratio diversity, as assessed by the Equitability of Pielou index, suggest a more uniform distribution of the species as is observed during the Skeletonization stage. This may be related to decreased biomass and subsequent reduced food availability, reducing the diversity of insects that colonized the decomposing carcasses and resulting in increased dominance (Berger-Parker $=0.389$ ).

The accumulation curve for insect fauna species collected from the three carcasses did not reach an asymptote, a situation often observed in other similar studies (LOPES et al. 2007; SousA 2008). The curve suggests the need for a greater sampling effort to observe rare species and to access the real wealth of the taxa in the study area. This result is consistent with findings in the Neotropical region where there are highly diverse insect species (Sousa 2008). Furthermore, there was a limited abundance of most species due to the low consistency of most species.

Knowledge of the standard succession of insects that colonize carcasses in specific geographic areas is relevant for determining the time of death. The information presented in this case study revealed the insect fauna observed on cadaverous carcasses and the pattern of colonization in southern Brazil. The results from this study indicate key species colonizing the carcasses during each decomposition stage that was considered. Based on indices of species dominance, the following species were prevalent in the various stages indicated: (I) Fresh - L. eximia; (II) Chromatic and (III) Bloat - C. albiceps; (IV) Black Putrefaction and (V) Skeletonization - Aphodiinae sp. 1. However, this pattern may vary under other environmental conditions, emphasizing the need for similar studies in this geographical area.

The use of forensic entomology as a routine tool in criminal forensic cases in the state is still facing many challenges. However, significant improvements can be made with respect to standardizing the methods used based on the knowledge of systems, taxonomy and insect ecology. The study of insect fauna associated with decaying carcasses, the definition of decomposition stages for a given geographic area and the relationship with abiotic factors are key elements for establishing a database for future use in criminal investigations.

\section{ACKNOWLEDGMENTS}

I am grateful to the following researchers for entomologic material identification: José Roberto Pujol-Luz and the staff at the Núcleo de Entomologia Forense at the Universidade de Brasília (Calliphoridae), Claudio Barros de Carvalho (Muscidae), Fernando Leiva and Kléber Mise (Histerid) at the Universidade Federal do Paraná, Cátia Antunes Mello-Patiu (Sarcophagidae) of the Museu Nacional at the Universidade Federal do Rio de Janeiro, Luciano de Azevedo Moura (Coleoptera) from the Fundação Zoobotânica do Rio Grande do Sul, Jocelia Grazia

(Hemiptera) of the Universidade Federal do Rio Grande do Sul and Katia Matiotti (Orthoptera) from the Pontifícia Universidade Católica do Rio Grande do Sul.

\section{REFERENCES}

Anderson, G.S. \& N. R. Hobischak, 2004. Decomposition of carrion in the marine environment in British Columbia, Canada. International Journal of Legal Medicine, 118: 206209.

Anderson, G.S. \& S. L. VanLaerhoven, 1996. Initial studies on insect succession on carrion in Southwestern British Columbia. Journal of Forensic Science, 41: 617-625.

Anderson, G.S., 2011. Comparison of decomposition rates and faunal colonization in indoor and outdoor environments. Journal of Forensic Science, 56: 136-142.

Archer, M.S., 2004. Rainfall and temperature effects on the decomposition rate of exposed neonatal remains. Science \& Justice, 44: 35-42.

Bornemissza, G.F., 1956. An analysis of arthropod succession in carrion and the effect of its decomposition on the soil fauna. Australian Journal of Zoology, 5: 1-12.

Campobasso, C.P., D. Vella \& F. Introna, 2001. Factors affecting decomposition and Diptera colonization. Forensic Science International, 120: 18-27.

Carvalho, L.M.L. \& A.X. Linhares, 2001. Seasonality of insect succession and pig carcass decomposition in a natural forest area in Southeastern Brazil. Journal of Forensic Science, 46: 604-608.

Carvalho, L.M.L., P.J. Thyssen, M.L. Goff \& A.X. Linhares, 2004. Observations on the sucession patterns of necrophagous insects onto a pig carcass in a urban area of Southeastern Brazil. Aggrawal's Internet Journal of Forensic Medicine and Toxicology, 5: 33-39.

Catts, E.P. \& N.H. Haskell (Eds), 1990. Entomology and death: a procedural guide. Clemsom, SC: Joyce's Print Shop, 184p.

Clarke, K.R. \& R.N. Gorley, 2006. Primer v6: User Manual/ Tutorial. Plymouth Marine Laboratory, Plymouth, 192 p.

Cruz, T.M. \& S.D. Vasconcelos, 2006. Entomofauna de solo associada à decomposição de carcaça de suíno em um fragmento de Mata Atlântica de Pernambuco, Brasil. Biociências, 14: 193-201.

Dillon, L.C., 1997. Insect succession on carrion in three biogeoclimatic zones in British Columbia. Dept. of Biological Sciences. Simon Fraser University, Burnaby B.C. Technical Report, 76 p.

Embrapa, 1999. Centro Nacional de Pesquisa de Solos (Rio de Janeiro, RJ). Sistema brasileiro de classificação de solos. Brasília. Embrapa-SPI, 412 p.

Faria, L.D.B., L.A. Trinca \& W.A.C. Godoy, 2004. Cannibalistic behavior and functional response in Chrysomya albiceps (Diptera: Calliphoridae). Journal of Insect Behavior, 17: 251261.

Ferreira, M.J.M., 1978. Sinantropia de dípteros muscoideos de Curitiba, Paraná. I. Calliphoridae. Revista Brasileira de Biologia, 38: 445-454p.

Friebe, B., 1983. Zur Biologie eines Buchenwaldbodens: 3 Die Katerfauna. Carolinea, 41: 45-80.

Goff, M.L. \& W.D. Lord, 1994. Entomotoxicology: a new area for forensic investigation. American Journal of Forensic Medicine and Pathology, 15: 51-57.

Goff, M.L., 1993. Estimation of postmortem interval using arthropod development and successional patterns. Forensic Science Review, 5: 81-94.

Gomes, H., 1997. Medicina Legal. 32ed. Rio de Janeiro, Freitas Bastos, 846 p.

Greenberg, B., 1991. Flies as forensic indicators. Journal of Medical Entomology, 28: 565-577.

Gregor, F. \& D. Polvony, 1958. Versuch einer Klassifikation der synanthropen Fliegen. Journal of Hygiene Epidemiology Microbiology and Immunology, 2: 205-216. 
Guimarães, J.H., A.P. Prado \& A.X. Linhares, 1978. Three newly introduced blowfly species in Southern Brazil (Diptera:Calliphoridae). Revista Brasileira de Entomologia, 22: $53-60$.

Guimarães, J.H., N. Papavero \& A.P. Prado, 1983. As miĺases na região neotropical (identificação, biologia, bibliografia). Revista Brasileira de Zoologia, 4: 239-416.

Hammer, Ø., D.A.T Harper \& P.D. Ryan, 2001. PAST: Paleontological Statistics Software Package for Education and Data Analysis. Palaeontologia Electronica, 4, 9pp.

IBGE (Instituto Brasileiro de Geografia e Estatística), 2013. Available in: <http://www.ibge.gov.br> [Accessed in: 02 January 2013]

INMET (Instituto Nacional de Meteorologia), 2012. Dados Climatológicos. Available in: <http://www.inmet.gov.br/ portal/> [Accessed in: 04 December 2012]

Introna, F., C.P. Campobasso \& M.L. Goff, 2001. Entomotoxicology. Forensic Science International, 120: 4247.

Kearns, C.A. \& D.W. Inouye, 1993. Techniques for pollination biologists. University of Texas Press, 583 p.

Krebs, C.J., 1999. Ecological Methodology. 2ed. Benjamin Cummings, Menlo Park, California, 620 p.

Kuinchtner, A. \& G.A. Buriol, 2001. Clima do Estado do Rio Grande do Sul segundo a classificação climática de Köppen e Thornthwaite. Disciplinarum Scientia, 2: 171-182.

Lopes, L.A., B. Blochtein \& A.P. Ott, 2007. Diversidade de insetos antófilos em áreas com reflorestamento de eucalipto, Município de Triunfo, Rio Grande do Sul, Brasil. Iheringia Serie Zoologia, 97: 181-193.

Maluf, J.R.T. \& M.R.R. Caiaffo, 2001. Regiões Ecoclimáticas do Estado do Rio Grande do Sul. In: XII Congresso Brasileiro de Agrometeorologia e III Reunião Latino-Americana de Agrometeorologia. Fortaleza, 151-152.

Marinoni, R.C., N.G. Ganho, L.M. Monne \& J.R.M. Mermudes, 2001. Hábitos alimentares em Coleoptera (Insecta). Ribeirão Preto: Holos Editora, 63 p.

Martinez, E., P. Duque \& M. Wolff, 2007. Succession pattern of carrion-feeding insects in Paramo, Colombia. Forensic Science International, 166: 182-189.

Mise, K.M., L.L. Almeida \& M.O. Moura, 2007. Levantamento da fauna de Coleoptera que habita a carcaça de Sus scrofa L., em Curitiba, Paraná. Revista Brasileira Entomologia, 51: 358-368.

Monteiro-Filho, E.L.A. \& J.L. Penereiro, 1987. Estudo de decomposição e sucessão sobre uma carcaça animal numa área do estado de São Paulo, Brasil. Revista Brasileira de Biologia, 47: 289-295.

Moreno, J.A., 1961. Clima do Rio Grande do Sul. Porto Alegre: Secretaria da Agricultura, $42 \mathrm{p}$.

Moura, M.O., C.J.B. Carvalho \& E.L.A. Monteiro-Filho, 1997. A preliminary analysis of insects of medico-legal importance in Curitiba, State of Paraná. Memórias do Instituto Oswaldo Cruz, 92: 269-274.

Oliveira, T.C. \& S.D. Vasconcelos, 2010. Insects (Diptera) associated with cadavers at the Institute of Legal Medicine in Pernambuco, Brazil and its implications for forensic entomology. Forensic Science International, 198: 97-102.
Payne, J.A., 1965. A summer carrion study of the baby pig Sus Scrofa. Ecology, 46: 592-602.

Prado, A.P. \& J.H. Guimarães, 1982. Estado atual de dispersão e distribuição do gênero Chrysomya Robineau-Desvoidy na região Neotropical (Diptera:Calliphoridae). Revista Brasileira de Entomologia, 26: 225-231.

Rodriguez, W.C. \& W.M. Bass, 1983. Insect activity and its relationship to decay rates of human cadavers in east Tennessee. Journal of Forensic Science, 28: 423-432.

Rosa, T.A., M.L.Y. Babata, C.M. Souza, D. Sousa, C.A. MelloPatiu, F.Z. Vaz-de-Mello \& J. Mendes, 2011. Arthropods associated with pig carrion in two vegetation profiles of Cerrado in the State of Minas Gerais, Brazil. Revista Brasileira de Entomologia, 55:424-434.

Scholtz, C. \& V.V. Grebennikov, 2005. Scarabaeiformia. In: Beutel, R.G. \& R.A.B. Leschen (Eds.). Coleoptera, Vol. 1: Morphology and Systematics (Archostemata, Adephaga, Myxophaga, Polyphaga partim). Handbook of Zoology IV (38). Berlin, Walter de Gruyter, 345-425.

Shean, B.S., L. Messinger \& M. Papworth, 1993. Observations of diferencial decomposition on sun exposed v. shaded pig carrion in coastal Washington State. Journal of Forensic Science, 38: 938-949.

Silveira Neto, S., O. Nakano, D. Barbin \& N.A. Villa Nova, 1976. Manual de ecologia dos insetos. Piracicaba: Ceres, 419 p.

Smith, K.G.V., 1986. A Manual of Forensic Entomology. British Museum (Natural History), London, $205 \mathrm{p}$.

Sousa, J.R.P., 2008. A fauna de califorídeos e sarcofagídeos (Insecta, Diptera) das matas e clareiras com diferentes coberturas vegetais da base de extração petrolífera, Bacia do Rio Urucu, Coari, Amazonas. Dissertation - Universidade Federal do Pará. 137p.

Souza, A.M. \& A.X. Linhares, 1997. Diptera and Coleoptera of potential forencic importance in southeasthern Brazil: Relative abundance and seasonality. Medical and Veterinary Entomology, 11: 8-12.

SPSS (Statistical Package for the Social Sciences), 2006. Version 12.0. [Computer program]. SPSS Inc: Chicago.

Stevens, J.R., 2003. The evolution of myiasis in blowflies (Calliphoridae). International Journal for Parasitology, 33: 1105-1113.

Vasconcelos, S.D. \& M.C.S. Araujo, 2012. Necrophagous species of Diptera and Coleoptera in northeastern Brazil: state of the art and challenges for the Forensic Entomologist. Revista Brasileira de Entomologia, 56: 7-14.

Vianna, E.E.S., P.R.P. Costa, A.L. Fernandes \& P.B. Ribeiro, 2004. Abundância e flutuação populacional das espécies de Chrysomya (Diptera, Calliphoridae) em Pelotas, Rio Grande do Sul, Brasil. Iheringia Série Zoologia, 94: 231-234.

Zumpt, F., 1965. Myiasis in man and animals in the Old World. A Textbook for Physicians, Veterinarians and Zoologists. London, $267 \mathrm{p}$.

Received in: 10/14/2014

Accepted in: 05/18/2015 $* * * * * * * * * *$
Suggested citation:

Ries, A.C. \& B. Blochtein, 2015. Insect Fauna Associated with Exposed Pig Carcasses in Southern Brazil. EntomoBrasilis, 8 (3): 180-188.

Available in: doi:10.12741/ebrasilis.v8i3.481
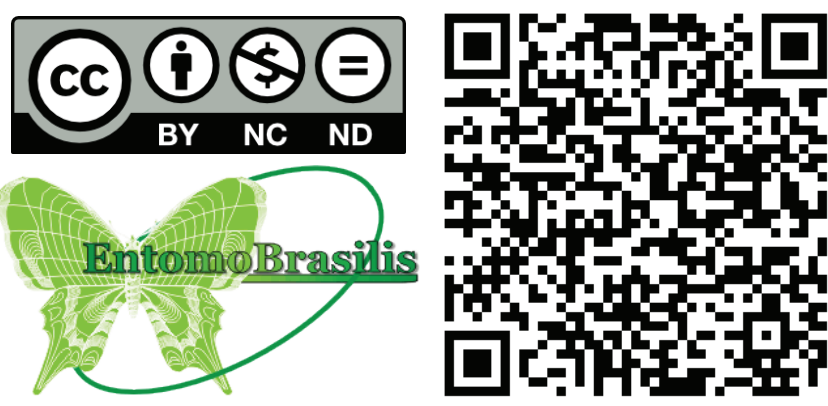